\title{
Genetic susceptibility of Henoch-Schönlein purpura in children
}

\author{
Ritu Aggarwal*, Anju Gupta, Jasmine Naru, Neha Nanda, Manila Salaria, Deepti Suri, Surjit Singh \\ From International Conference on Human Genetics and 39th Annual Meeting of the Indian Society of \\ Human Genetics (ISHG) \\ Ahmadabad, India. 23-25 January 2013
}

\section{Background}

Henoch-Schönlein purpura (HSP) is a small vessel vasculitis typically observed in children, 3-10 years old. The aetiology is unclear. Interaction of several environmental factors, including infections and multiple genes has been proposed to play a role in pathogenesis. An increased familial occurrence is an indicator of genetic predisposition; association with a major histocompatibility complex is plausible. The aim of the study was to investigate the association of HLA-DRB1 (HLA class II antigen) with HSP.

\section{Subjects and methods}

The study was prospective and hospital based. Patients up to the age of 14 years, who fulfilled the diagnostic criteria of HSP, laid by the 'European League Against Rheumatism' were enrolled. Age matched healthy controls were included as well. One $\mathrm{ml}$ blood in EDTA was collected from patients as well as controls. DNA extraction was performed using commercially available kit. The quantity and quality of DNA was estimated by spectrophotometer and PCR for housekeeping gene beta actin, respectively. PCR with 24 sequence specific primers for HLA-DRB1 antigen was performed. Commercially available HLA-DR tissue typing kit (Inno-train, Kronberg im Taunus, Hesse, Germany) was utilized. Frequency of HLA-DRB1 was correlated with gastrointestinal and renal involvement.

\section{Results}

The study included 43 patients and 53 controls. The mean age of the patients and controls was 8.5 years (range: $3-14$ ) and 7.4 years (range: 1-14), respectively. Frequency of

\footnotetext{
* Correspondence: ritu_immunopath@yahoo.co.in Department of Immunopathology and Allergy and Immunology Unit, Deptartment of Pediatrics, Post Graduate Institute of Medical Education and Research, Chandigarh, India
}

Submit your next manuscript to BioMed Central and take full advantage of:

- Convenient online submission

- Thorough peer review

- No space constraints or color figure charges

- Immediate publication on acceptance

- Inclusion in PubMed, CAS, Scopus and Google Scholar

- Research which is freely available for redistribution 